industrial work. For work in the universities, the scholarships granted include one fellowship, seventeen studentships and twenty-seven bursaries. Twentyeight of the awards are to be used in financing graduate students in chemistry, including fourteen in physical chemistry, six in cellulose research, four in organic chemistry, two in general chemistry, one in inorganic chemistry and one on a practical chemical problem in the National Research Laboratories. Twelve candidates will work in physics, including three in the National Research Laboratories. Other divisions of science represented in the awards are: biochemistry, 2 ; biology, 2 ; botany, 1 ; entomology, 1 ; genetics, 2 ; and mathematics, 1.

\section{Rockefeller Travelling Fellowships in Medicine}

THE following Rockefeller travelling fellowships in medicine have been awarded by the Medical Research Council for the academic year 1938-39: R. R. Bomford, assistant physician, London Hospital; T. Colver, outpatient medical registrar, Hospital for Sick Children, Great Ormond Street, London ; R. M. Heggie, assistant lecturer in pathology and bacteriology, Welsh National School of Medicine, Cardiff; Ian MacKenzie, assistant surgeon, St. Giles's Hospital, London; Dr. G. G. E. Smyth, Dickinson research scholar, National Hospital, Queen Square, London; Ivor G. Williams, senior assistant radiotherapist, Meyerstein Institute of Radiotherapy, Middlesex Hospital. All these fellows propose to work at centres in the United States, with the exception of Dr. Smyth, who intends to study in Paris. Dr. Williams will hold his fellowship for six months only. In addition, the Rockefeller Foundation has awarded similar fellowships, on the recom. mendation of the Medical Research Council, to the following candidates in the special field of psychiatry, neurology and related subjects, all of whom are from the Maudsley Hospital, London : T. R. C. Fraser, W. W. Sargant, and M. J. F. McArdle.

\section{The World Power Conference}

WE have received from the Central Office of the World Power Conference, Kingsway, London, the annual report for 1937. Dr. William F. Durand is the president and Sir Harold Hartley is the chairman of the International Executive Council. The first conference was held in London in 1924, the second in Berlin in 1930 and the third in Washington in 1936. In addition, six other special meetings have been held. The next meeting of the council will take place in Vienna on August 29, 1938. The total number of National Committees of the World Power Conference is now 42, and in addition there are four member-countries with representatives. After the conference at Vienna this year there will be a studytour of about a week's duration. The Central Office continues to circulate to the National Committees and representatives, reports on the work being carried on by the International Special Committee on Radio Interference, under the auspices of the International Electrotechnical Commission.
'THE following appointments of official delegates to the sectional meeting of the World Power Conference to be held in Vienna on August 25-September 2, have been made : to represent the Government of the United Kingdom, Sir Harold Hartley (chairman, International Executive Council and chairman, British National Committee of the World Power Conference, and Mr. J. M. Kennedy, deputy-chairman, Electricity Commission; appointed by the British National Committee of the World Power Conference, Sir Archibald Page, chairman, Central Electricity Board, and Dr. F. S. Sinnatt, director of fuel research, Department of Scientific and Industrial Research. The total attendance from the United Kingdom will exceed eighty, which is a record for any sectional meeting of the World Power Conference held abroad.

\section{International Management Congress}

STRoNG British support has been secured for the seventh International Management Congress which meets in Washington, D.C., on September 19-24. More than ninety delegates, fully representative of British industry, are attending to support Lord Leverhulme, who is the president of the International Committee. An interesting unit of this party consists of nine young executives, one of whom is a lady, who are being assisted by bursaries paid out of the funds remaining from the sixth Inter. national Congress held in 1935 in London. This party will travel together as a unit under the leadership of Dr. E. F. Armstrong : it is anticipated that each will profit from the collective experience of the whole. Four tours by motor coach have been organized, enabling the delegates to visit a number of factories and cities. Before the Congress, there is one tour of six days in New England and a second, taking five days, to the highly industrialized country between New York and Washington. After the Congress, an eleven-day tour goes through the midWest to Chicago and back to New York via Buffalo and Niagara, and there is a final short tour to Boston. It is proposed to give some form of written report of the visits, which will serve as a permanent record. The tours are likely to be of exceptional educational value from the point of view of scientific management. About 250 papers from some twenty countries have been accepted by the Congress. The papers of each technical section have been summarized. The chairman of the Congress Council is Mr. Willis H. Booth, vice-president of the Guaranty Trust Company ; that of the Co-ordinating Committee is $\mathrm{Mr}$. William $\mathrm{L}$. Batt, president of S. K. F. Industries; whilst the chairman of the Organizing Committee is Mr. Harry A. Hopf, well known as one of the most active protagonists of the management movement. The delegates will be welcomed by Mr. Cordell Hull, and there will be a formal reception at the White House.

\section{International Scientific Radio Union}

TнE sixth General Assembly of the International Scientific Radio Union (Union Radio Scientifique Internationale) will be held in Italy on September 4-14. The U.R.S.I. is one of the constituent bodies 
of the International Council of Scientific Unions, with its secretariat in Brussels ; and it is concerned with the various scientific aspects of radio communication and radio physics, in many branches of which international discussion and co-operation is beneficial in stimulating both theoretical and experimental research. At the previous general assembly of the U.R.S.I. held in London in 1934, Prof. E. V. Appleton was elected president, and he is also chairman of the British National Committee, of which Dr. E. H. Rayner is secretary. Other members of this committee who will be attending the forthcoming meeting in Italy include Prof. S. Chapman, Mr. T. E. Eckersley, Mr. E. B. Moullin, Mr. J. A. Ratcliffe, Dr. R. L. Smith-Rose and Mr. R. A. Watson Watt. It is anticipated that representatives of some twelve or more other nations will also be in attendance. The work of the General Assembly is divided among five commissions dealing respectively with radio measurements and standards, the propagation of waves, atmospherics, liaison and radio physics. The opening meeting will take place on September 4 at Venice, where most of the business of the Assembly will be carried out during the ensuing week. The formal closing meeting takes place in Rome, and various technical visits and other appropriate engagements of interest are included in the programme.

\section{Imperial Veterinary Conference}

AN Imperial Veterinary Conference will be held at the Royal Veterinary College, Camden Town, London, N.W.1, on August 15-19. The subjects to be discussed will include the work of the Imperial Bureau of Animal Health, foot-and-mouth disease and certain other virus diseases, Johne's disease, bovine mastitis, caseous lymphadenitis of sheep, sheep blowflies, fowl paralysis and chronic bovine hæmaturia.

\section{Announcements}

The Jenner Medal of the Royal Society of Medicine, which is awarded for distinguished work in epidemiological research or for pre-eminence in the prevention and control of epidemic disease, was presented to Sir Arthur Newsholme on July 19.

THळ Queen Mary has established a new record for the east to west crossing of the Atlantic. She berthed at New York on August 8, after having covered the distance from the Bishop Rock to the Ambrose Channel lightship in 3 days 21 hours 48 minutes, at an average speed of 30.99 knots.

IT is announced by the Berlin correspondent of The Times that a new height record for a glider was set up at Wasserkuppe by Capt. Walther Drechsel on August 5, when he ascended to $23,190 \mathrm{ft}$. The machine, a Minimoa glider, was towed to a height of about $3000 \mathrm{ft}$. and then released.

THRough the generosity of the late Mr. Herbert Harlow of Bradford, the Bradford Technical College has been able to establish a Harlow fellowship of the value of $£ 250$ a year for research to be carried out at the Technical College, Bradford, in one of the branches of science relating to the textile industry or the dyeing industry. Mr. R. Williamson has been appointed to the first fellowship.

AN Advisory Committee on Blindness, including its prevention and treatment, has recently been formed by the Minister of Health. The following have been appointed members of the Committee : Dr. P. M. Evans (chairman), H. R. Bickerton, J. D. Magor Cardell, Miss Grace Cracknall, James Ferguson, Percy Fleming, N. Bishop Harman, Dr. E. K. Macdonald, Miss Ida Mann, R. Foster Moore, G. F. Mowatt, Sir John Parsons and A. H. H. Sinclair. The Committee has been appointed for a period of three years. Mr. H. G. Benjamin, of the Ministry of Health, will be secretary, and Dr. A. E. Hallinan, of the Ministry of Health, will be medical secretary of the Committee.

THE following awards for 1938-39 have been made by the Salters' Institute of Industrial Chemistry and approved by the Court of the Salters' Company. Fellowships have been renewed in the case of Messrs. A. J. Shorter (to the University of Illinois), J. L. Tuck (at the University of Oxford) and to S. H. Wade (at Imperial College, London). Fellowships have been awarded to H. D. Anderson (University of Oxford), A. Cameron (Imperial College, London), H. S. Corran (University of Cambridge) and R. N. Haward (University of Cambridge). The Salters' Institute has also awarded fifty grants-in-aid to young men employed in chemical works in or near London to assist them in their studies.

THE following appointments and promotion have been made in the Colonial Service: H. C. Thorpe to be plant breeder, Kenya; M. H. C. Glyn, to be veterinary officer, Northern Rhodesia; W. G. G. Pevie, to be veterinary officer, Tanganyika Territory; D. A. Frye, to be assistant analyst, Analyst's Department, Straits Settlements; J. R. E. Hindson (agricultural superintendent, Gold Coast), to be agricultural officer, Northern Rhodesia; R. M. Nattrass (plant pathologist, Cyprus), to be senior plant pathologist, Kenya ; Gunn Lay Teik (assistant analyst), to be chemist, Department of Agriculture, Federated Malay States ; W. Molegode (officer of Class I, Grade I, Agricultural Department), to be agricultural officer (Propaganda), Ceylon.

Dr. Wendell Meredith Stanley, of the Rockefeller Institute, Princeton, has been awarded the Rosenberger Medal of the University of Chicago in recognition of his isolation of erystalline forms of the filtrable viruses. The Rosenberger Medal for distinguished achievement in the advancement of learning or for notably great service in the promotion of human welfare has been awarded five times previously.

THE first International Congress for Forensic and Social Medicine will be held at Bonn on September 22-24 under the presidency of Prof. Pietrusky, director of the Bonn Institute of Forensic Medicine. Further information can be obtained from Prof. Schrader, Franzosenweg 1, Halle a.d.S. 